DOI: https://doi.org/10.47405/mjssh.v5i6.428

\begin{tabular}{|c|c|}
\hline 1. 1.54 & Malaysian Journal of Social Sciences and Humanities (MJSSH) \\
\hline $\begin{array}{c}\text { Malaysian Journal of } \\
\text { solal sciences and }\end{array}$ & Volume 5, Issue 6, June 2020 \\
\hline (MJ-SSH) & e-ISSN : 2504-8562 \\
\hline & $\begin{array}{l}\text { Journal home page: } \\
\text { www.msocialsciences.com }\end{array}$ \\
\hline
\end{tabular}

\title{
Elemen Kerohanian dalam Program Kebersihan Sekolah Menengah di Negeri Selangor Darul Ehsan
}

\author{
Mohd Taufik Mohd Ayup', Ahmad Nasir Mohd Yusoff', Arfah Ab. Majid1 \\ ${ }_{1}^{1}$ Jabatan Pengajian Kenegaraan dan Ketamadunan, Fakulti Ekologi Manusia, Universiti Putra Malaysia (UPM) \\ Correspondence: Ahmad Nasir Mohd Yusoff (ahmadnasir@upm.edu.my)
}

\begin{abstract}
Abstrak
Kebersihan kawasan persekitaran yang baik mendorong pelestarian sebuah tamadun yang stabil. Pada tahun 2004, Kementerian Pendidikan Malaysia (KPM) telah memperkenalkan Program Peningkatan Keselamatan, Kebersihan dan Keindahan Alam Sekitar Sekolah (Program 3K). Program ini merupakan penambahbaikan kepada program sedia ada iaitu Program Sekolah Selamat, Program Kesihatan dan Kebersihan serta Program Keceriaan dan Keindahan Sekolah yang dimulakan sejak tahun 1991. Program ini berjaya mengubah pemandangan kawasan sekolah yang lebih ceria dan selamat. Kajian ini berhasrat melihat keberkesanan Program 3K dengan mengenal pasti persepsi, tingkah laku positif dan pembentukan sahsiah pelajar. Hasil kajian mendapati beberapa perkara penting antaranya; secara keseluruhan pengetahuan pelajar terhadap Program 3K berada pada tahap sederhana, secara keseluruhan penerapan elemen-elemen Kerohanian dalam program penjagaan kebersihan dalam Program 3K adalah pada tahap sederhana, persepsi pelajar terhadap keberkesanan Program $3 \mathrm{~K}$ di sekolah khususnya komponen kebersihan adalah positif, tingkah laku pelajar terhadap penjagaan kebersihan di luar kawasan sekolah adalah positif, persepsi pelajar terhadap tanggungjawab menjaga kebersihan adalah negatif dan perkaitan songsang antara tahap pengetahuan dengan tingkah laku pelajar iaitu semakin tinggi tahap pengetahuan pelajar semakin rendah akhlak pelajar. Data dikumpul melalui pengedaran borang soal selidik. Alat kajian yang digunakan dibina sendiri dengan perbincangan bersama penyelia. Soal selidik diedarkan kepada 300 pelajar di negeri Selangor. Data yang diperoleh diproses menggunakan perisian IBM SPSS Statistics 20. Teknik analisis deskriptif digunakan untuk menilai tahap pengetahuan dan persepsi, ujian-t untuk melihat perbezaan antara pelajar bandar dengan luar bandar dan korelasi bagi melihat perkaitan tahap pengetahuan pelajar terhadap tingkah laku pelajar. Keputusan boleh disimpulkan bahawa tahap pengetahuan pelajar terhadap Program $3 \mathrm{~K}$ tidak mendorong perilaku positif pelajar dalam menjaga kebersihan kawasan persekitaran. Hal ini disebabkan pelaksanaan dan penerapan aspek kerohanian begitu lemah dan tidak diberikan perhatian dalam membina perilaku dan jati diri pelajar. Hal ini tidak menepati FPK yang bermatlamatkan pelajar seimbang dan menyeluruh dengan menerapkan empat komponen iaitu jasmani, emosi, rohani dan intelek.
\end{abstract}

Kata kunci: elemen, kerohanian, program, kebersihan, sekolah menengah

\section{Spiritual Elements in the Secondary School Cleanup Program in Selangor}

\begin{abstract}
The cleanliness of the surrounding environment promotes the preservation of a stable civilization. In 2004, the Ministry of Education Malaysia (MOE) introduced the School Safety, Cleanliness and
\end{abstract}


Environmental Improvement Program (3K Program). The program is an extension of the existing Safe Schools, Health and Sanitation Program and School Fun and Beauty Program which has been in operation since 1991. The program has transformed the look of a more vibrant and safe school district. This study aims to look at the effectiveness of the $3 \mathrm{~K}$ Program by identifying students' perceptions, positive behaviors and character building. The results of the study revealed several important issues; overall students 'knowledge of the $3 \mathrm{~K}$ Program is at a moderate level, overall the application of the Spiritual elements of the hygiene program in the $3 \mathrm{~K}$ Program is at a moderate level, students' perceptions of the effectiveness of the $3 \mathrm{~K}$ Program in schools especially the hygiene component is positive, student behavior towards care Out-of-school hygiene is positive, students' perception of the responsibility of maintaining hygiene is negative and the inverse relationship between student's level of knowledge and behavior is that the higher the student's knowledge level, the lower the morale of the students. Data is collected through the distribution of questionnaire forms. The research tool used was developed in consultation with the supervisor. The questionnaire was distributed to 300 students in the state of Selangor. Data obtained were processed using IBM SPSS Statistics software 20. Descriptive analysis techniques were used to assess levels of knowledge and perceptions, t-tests to examine differences between urban and rural students and correlations to see the relevance of students' knowledge levels to student behavior. The results can be concluded that the level of student knowledge of the $3 \mathrm{~K}$ Program does not encourage positive student behavior in maintaining environmental cleanliness. This is because the implementation and application of spiritual aspects are so weak that they are not given attention in building student behavior and identity. This does not meet the FPK that keeps students balanced and comprehensive by applying four components, namely physical, emotional, spiritual and intellectual.

Keywords: element, spirituality, program, cleanliness, high school

\section{Pengenalan}

Menjaga kebersihan kawasan sekitar bukan perkara kecil dalam agenda pembangunan negara. Isu kebersihan sampah sarap yang dibincangkan bukan lagi perkara asing. Isu sampah misalnya, merupakan isu sejagat yang sering dipaparkan di kaca televisyen yang menunjukkan sampah sarap terapung-apung di permukaan laut, sungai mahupun yang tenggelam hingga ke dasar laut dan akhirnya memusnahkan hidupan laut serta menganggu ekosistem. Penjagaan kebersihan kawasan sekitar menjadi perkara yang kurang dibincangkan atau tidak mendapat tempat dalam jiwa masyarakat. Malahan ia sekadar perkara pilihan sama ada mahu mengambil bahagian dalam aktiviti-aktiviti penjagaan kebersihan kawasan sekitar, atau mengambil bahagian dalam aktiviti-aktiviti penjagaan kebersihan secara serius atau sekadar sambilan sahaja mengikut mood dan agenda mesyuarat.

Segelintir masyarakat memandang remeh berkaitan penjagaan kebersihan dan persekitaran. Penjagaan kebersihan ini berkait rapat dengan keimanan, ketakwaan dan kebahagiaan hidup. Bukan sahaja di rumah kebersihan perlu dijaga, tetapi juga di tempat kerja. Pengabaian dalam menjaga kebersihan mempamerkan gaya hidup masyarakat yang hanya terdidik dengan undang-undang dan peraturan semata-mata, tingkah laku manusia akan berubah-ubah mengikut tempat kerana undang-undang dan peraturan berbeza-beza bagi setiap tempat. Sebaliknya, apabila diri manusia dididik dengan keimanan, manusia tidak memerlukan undang-undang dan peraturan untuk menjaga tingkah laku kerana akhlak mulia menjadi gaya hidup orang beriman pada bila-bila masa dan di mana jua berada.

Dalam sesebuah negara, agenda menjaga kebersihan kawasan persekitaran perlu sentiasa lestari atau ditambah baik dari semasa ke semasa. Kebersihan kawasan persekitaran yang baik mendorong pelestarian sebuah tamadun yang lebih stabil. Bapa Ketamadunan, Ibn Khaldun dalam buku beliau 'alMuqadimah' (Introduction) turut membicarakan soal kebersihan. Dalam aspek pencemaran, beliau menghuraikan kepentingan menjaga kebersihan udara di kawasan yang didiami. Gas-gas kotor yang terbebas ke udara akan mencemarkan udara yang bersih. Justeru, ia akan mengganggu kesihatan masyarakat setempat. Kesihatan masyarakat yang merundum akan menjadikan masyarakat semakin lemah dan lebih mudah menghidap pelbagai penyakit. 
Tambah Ibn Khaldun lagi, demi menjaga bandar daripada bahaya yang ada hubungannya dengan gejala atmosfera, hendaklah diperhatikan supaya adanya pengaliran udara yang bersih segar. Sekiranya udara itu tidak bersih dan beku atau berdekatan dengan air yang busuk atau kolam yang busuk atau paya yang tengik airnya, dengan cepatnya kebersihan udara akan tercemar dan tidak dapat dihindari daripada dihinggapi penyakit. Hakikat ini dapat disaksikan melalui pengamatan langsung.

Amalan menjaga kebersihan, keindahan dan keselamatan telah diberikan perhatian dalam sistem pendidikan sekolah-sekolah di Malaysia. Pada tahun 2004, Kementerian Pendidikan Malaysia memperkenalkan Program Peningkatan Keselamatan, Kebersihan dan Keindahan Alam Sekitar Sekolah atau Program 3K. Program ini merupakan penambahbaikan kepada program sedia ada merangkumi tiga program berasingan iaitu Program Sekolah Selamat, Program Kesihatan dan Kebersihan serta Program Keceriaan dan Keindahan Sekolah yang mula diperkenalkan pada tahun 1991. Program 3K ini dijadikan sebagai Inisiatif Meningkatkan Keselamatan, Kesihatan dan Keceriaan Sekolah (Kementerian Pendidikan Malaysia, 2012). Program ini nampak berjaya mengubah pemandangan kawasan sekolah yang lebih ceria dan selamat. Boleh dikatakan pada setiap sekolah masa kini landskap suasana dan panorama persekitaran sekolah sudah berubah dengan pelbagai jenis pokok bungaan dan tanaman ditanam dan dihias di sekitar kawasan sekolah bagi tujuan keceriaan kawasan sekolah.

Secara umumnya, program 3K sangat menitikberatkan perubahan fizikal sekolah menjadikan sekolah lebih bersih, ceria dan selamat. Tambahan lagi, pihak kementerian menyediakan anugerah pelbagai kategori kepada sekolah-sekolah yang berusaha menjayakan program ini. Hal ini menjadikan pihak sekolah lebih bermotivasi dan bersemangat untuk terus konsisten menceriakan persekitaran sekolah masing-masing.

Aspek kerohanian perlu diterapkan dengan bersungguh-sungguh sama seperti usaha yang dilakukan dalam pembinaan keupayaan intelek pendidikan sebenar. Pendidikan sebenar adalah pendidikan yang bermatlamat untuk memperoleh kebahagiaan hidup di dunia dan di akhirat sepertimana matlamat dalam Falsafah Pendidikan Kebangsaan iaitu "...mencapai kesejahteraan diri...". Kesejahteraan bukan sahaja perlu keupayaan intelek, malah kekuatan kerohanian turut dibangunkan. Kesejahteraan atau kebahagiaan di dunia sahaja tanpa mengejar akhirat adalah sebuah kehidupan yang tidak lebih daripada sebuah tipu daya yang akhirnya mendapat kerugian yang sia-sia. Untuk itu, elemen kerohanian mesti diterapkan. Perihal kerohanian dalam Islam ada kaitan dengan keimanan, ketakwaan dan kehidupan selepas mati. Pada masa yang sama jika perkara ini dilakukan ia menjadi usaha dakwah kepada masyarakat yang berjinak-jinak dengan Islam.

Tuntasnya, suasana dan pemandangan kawasan sekolah yang kelihatan bersih, ceria dan selamat sememangnya lebih mudah dicapai apabila terdapat lebih ramai pekerja tukang cuci dan tukang kebun di sekolah. Namun, adakah apabila kawasan sekolah kelihatan bersih, indah dan selamat berupaya mendorong berlaku perubahan positif terhadap tingkah laku pelajar?

\section{Sorotan Literatur}

Amir Hamzah dan Chin (2012) dalam kajian mereka iaitu kajian tentang sikap dan amalan murid sekolah rendah mengenai konsep lestari mendapati bahawa pengetahuan murid tentang konsep lestari adalah pada tahap sederhana, manakala amalan dan sikap kelestarian pula adalah pada tahap yang baik. Pengetahuan murid yang sederhana tetapi amalan mereka yang baik menunjukkan bahawa dua perkara yang berasingan iaitu tiada perkaitan antara pengetahuan dengan amalan (Amir \& Chin, 2012). Hal ini menggambarkan bahawa murid sekolah rendah ramai yang masih tidak faham tentang konsep-konsep lestari yang diajar. Walau bagaimanapun, prestasi amalan murid adalah pada tahap yang baik. Penulis berpandangan bahawa amalan mereka pada prestasi yang baik adalah kerana murid-murid mengamalkan amalan lestari seperti berjimat dalam penggunaan air dan elektrik, menjaga kebersihan dan menanam pokok tanpa mengetahui bahawa amalan-amalan tersebut merupakan amalan lestari 
Sebuah kajian yang dilakukan oleh Tan \& Norzaini (2011) mengkaji tentang tingkah laku alam sekitar dalam kalangan pelajar universiti. Hasil kajian tersebut mendapati bahawa tahap komitmen responden terhadap alam sekitar adalah pada tahap yang tinggi. Walau bagaimanapun, hasil kajian juga mendapati bahawa tingkah laku mesra alam sekitar dalam kalangan pelajar tersebut adalah rendah. Selain itu juga, hasil kajian mendapati bahawa tidak terdapat hubungan yang signifikan antara komitmen terhadap alam sekitar dengan tingkah laku mesra alam sekitar (Tan \& Norzaini, 2011).

Dalam kajian persepsi dan penyertaan terhadap kefahaman tentang warga alam sekitar mendapati bahawa masyarakat belia negara ini pada hakikatnya telahpun sedar dan faham akan kepentingan persekitaran yang baik. Akan tetapi sikap tidak peduli terhadap kebajikan orang lain atau pemeliharaan persekitaran sangat menebal dalam kalangan masyarakat negara ini (Abdul Latiff et al., 2012). Sikap tidak peduli ini menunjukkan betapa lemahnya nilai keprihatinan dan kerohanian masyarakat terhadap orang lain dan persekitaran. Menurut kajian itu lagi mendapati salah satu sebab persoalan ini timbul adalah disebabkan amalan ke arah pemeliharaan dan pemuliharaan alam sekitar yang sangat lemah sekali. Tiada role model yang dapat memberi rangsangan kepada masyarakat supaya amalan menjaga persekitaran menjadi budaya dalam masyarakat kita dan aktiviti-aktiviti yang melibatkan kepentingan komuniti kebanyakannya dianjurkan oleh pertubuhan-pertubuhan seperti badan agama dan persatuan yang mana aktiviti-aktiviti komuniti tersebut adalah tidak formal (Abdul Latiff et al., 2012). Hal ini secara tidak langsung memberi mesej kepada kita bahawa usaha ke arah penjagaan alam sekitar bukanlah matlamat utama dan perkara yang sering dianggap tidak begitu penting dalam pembangunan. Selain itu, sikap tidak peduli terhadap kebajikan orang lain juga dikatakan hilangnya sikap bertanggungjawab dalam sistem hidup bermasyarakat.

Sebuah kajian tentang tahap pengetahuan, sikap, kesedaran dengan kepemimpinan pendidikan alam sekitar dalam kalangan pengetua sekolah mendapati pengetua sekolah masih tidak mengambil kira faktor atau elemen persekitaran alam semula jadi dalam proses pengajaran dan pembelajaran di bilik darjah walaupun pengetua memiliki sikap yang positif terhadap alam sekitar selari dengan tahap kesedaran mereka yang tinggi (Azizi et al. n. d.). Hal ini merupakan kurangnya berlaku kejujuran dalam pendidikan.

\section{Permasalahan kajian}

Terdapat beberapa persoalan kajian yang dibincangkan antaranya adakah para pelajar sekolah menengah di negeri Selangor Darul Ehsan mengetahui dengan mendalam terhadap program penjagaan kebersihan dalam Program 3K di sekolah, adakah terdapat penerapan elemen-elemen kerohanian dalam program penjagaan kebersihan dalam Program $3 \mathrm{~K}$, apakah sebenarnya persepsi pelajar terhadap keberkesanan Program 3K di sekolah khususnya komponen kebersihan, bagaimanakah tingkah laku pelajar sekolah menengah terhadap penjagaan kebersihan persekitaran di kawasan sekolah khususnya di kawasan luar pagar sekolah? dan apakah persepsi pelajar terhadap tanggungjawab menjaga kebersihan kawasan persekitaran. Justeru itu, penyelidik berharap agar kajian ini menjadi panduan kepada pihak yang terlibat dalam menjaga kesejahteraan persekitaran secara berkesan dan efisien. Terdapat beberapa permasalahan isu kerohanian dan program kebersihan berdasarkan beberapa tulisan seperti:

Dalam paparan berita oleh Utusan bertarikh 16 Jun 2017 menyatakan gejala-gejala persekitaran awam dan alam sekitar berlaku melibatkan kes seperti tandas awam kotor, longkang tersumbat dan vandalisme mahupun kes yang besar seperti kes denggi yang tinggi di negeri Perak meningkat 101.6 peratus kes dan kebanyakan di negeri-negeri lain, berlakunya banjir kilat dan longkang tersumbat amat menghantui penduduk setempat dan punca penyakit Zika.

Kajian Zaini Ujang dalam buku Minda Lestari, 2009, menegaskan perlu juga disedari adakalanya di peringkat nasional negara kaya dengan pelbagai dasar dan peraturan yang mengalahkan kebanyakan negara maju, namun sayang, dasar-dasar tersebut sekadar luahan hasrat murni yang sukar diterjemahkan dalam bentuk amalan. Persoalan ini sememangnya berlegar-legar dalam kotak pemikiran penyelidik kerana apabila melihat isu kebersihan dan alam sekitar seperti tandas-tandas 
awam yang kotor dan sampah-sarap di kebanyakan kawasan awam masih lagi serius sehingga menyebabkan masalah kebersihan seperti wabak penyakit denggi dan saliran air tersumbat menyebabkan banjir kilat. Penyakit denggi terus menular sedangkan kempen-kempen kebersihan dan kesedaran mencegah denggi terus dijalankan serta kesedaran alam sekitar dalam sukatan pelajaran menerusi Pendidikan Islam dan Pendidikan Moral tentang kebersihan dan alam sekitar telah diajarkan kepada murid-murid sudah sekian lama. Masalah kebersihan di negara ini seperti sukar mendapat jalan penyelesaian, justeru menimbulkan satu persoalan lain iaitu apakah sebenarnya persepsi pelajar tentang tanggungjawab menjaga kebersihan awam sama ada dibahu pihak lain seperti pekerja tukang sapu kerajaan tempatan atau tanggungjawab kebersihan adalah tanggungjawab bersama.

Laporan kes-kes penularan wabak denggi oleh Kementerian Kesihatan Malaysia 2013, menyatakan wabak denggi sememangnya berkait rapat dengan masalah kebersihan awam pada tahap serius. Kegagalan menjaga kebersihan awam seperti membiarkan takungan air dalam sampah tong cat, tayar dan polisterin serta sampah-sarap dalam saliran air yang menyebabkan saliran air tersumbat dalam longkang dan parit menjadi tempat pembiakan nyamuk aedes dan mengundang wabak denggi sehingga membawa pesakit mengalami penderitaan dan kematian.

Laporan Kementerian Kesihatan Malaysia mengenai bilangan kes denggi di Malaysia sehingga hujung tahun 2013 berjumlah 23,829 kes berbanding 16, 729 pada tahun 2012, iaitu peningkatan sebanyak 7,1000 kes atau 42.4 peratus. Jumlah kumulatif kes kematian denggi pula adalah sebanyak 52 kematian, meningkat 25 kematian atau 92 peratus berbanding hanya 27 kematian pada tahun 2012 (Kementerian Kesihatan Malaysia, 2013). Bagi tahun 2014 pula, kes denggi meningkat lagi kepada 82,738 kes di seluruh negara. Bagi kes kematian akibat kompilasi Denggi sehingga 18 Oktober 2014 adalah sebanyak 157 kematian seluruh negara berbanding 59 kematian yang dilaporkan bagi tahun 2013. Kawasan-kawasan yang menyumbang kepada kadar pembiakan Aedes merupakan kawasan yang berhampiran dengan persekitaran aktiviti harian iaitu tanah perkuburan, tapak pembinaan, tanah/lot kosong, tempat ibadat, tempat pembuangan sampah, sekolah, taman rekreasi, pejabat kerajaan dan kilang (Kementerian Kesihatan Malaysia, 2014). Angka-angka kes denggi dan kematian akibat denggi adalah terus meningkat dari tahun ke tahun. Hal ini sekali lagi menggambarkan bahawa kesihatan persekitaran di negara ini amat rendah dan semakin rendah. Seakan-akan tiada tindakan dan strategi yang diambil oleh rakyat Malaysia ataupun tindakan yang semakin lemah. Angka pengidap penyakit denggi dan kematian akibat penyakit denggi yang meningkat menjadi indikator bahawa masyarakat Malaysia tidak mengamalkan tingkah laku positif terhadap kawasan persekitaran, malah menyumbang kepada kerosakan dan kekotoran kawasan persekitaran.

Menurut Timbalan Menteri Tenaga, Teknologi Hijau Dan Air pada ketika itu, Datuk Seri Mahdzir Khalid memberitahu sampah dengan beratan tiga tan telah tersumbat dan menyebabkan banjir kilat. Sampah yang tersumbat teruk mengakibatkan banjir kilat walaupun hujan lebat tidak sampai 30 minit. Air sungai melebihi tebing Sungai Bertam telah menenggelamkan Kampung Baru Ringlet dan seramai 91 orang dari 28 buah keluarga dipindahkan.

Dalam satu kajian tentang kesedaran alam sekitar yang mendakwa peranan ibu bapa dalam mempengaruhi tingkah laku dan persepsi anak-anak terhadap alam sekitar. Ibu bapa adalah insan yang cukup signifikan kerana mereka merupakan individu yang paling hampir dan merupakan "guru" yang pertama kepada anak-anak di rumah (Abdullah et al., 2013). Sikap dan tingkah laku anak-anak yang tidak berakhlak kepada alam dan persekitaran menunjukkan bahawa ibu bapa tidak mempunyai akhlak mulia terhadap alam sekitar dan persekitaran kerana ibu bapa yang menjadi contoh kepada anak-anak mereka.

\section{Objektif kajian}

Secara amnya, kajian ini dijalankan untuk mengenal pasti pengamalan elemen kerohanian dalam program penjagaan kebersihan dalam Program 3K di sekolah menengah di negeri Selangor Darul Ehsan. 


\section{Metod Kajian}

Berdasarkan kepada tajuk penyelidikan yang dicadangkan, penyelidik telah memilih kajian yang berbentuk kuantitatif. di mana ianya menggunakan kaedah soal selidik dan tinjauan disebabkan populasi pelajar sekolah menengah di negeri Selangor Darul Ehsan begitu ramai. Reka bentuk tinjauan dapat mengambil saiz sampel yang lebih besar dan data dapat dikumpul dengan cepat. Penyelidik mengedar soal selidik kepada responden untuk dijawab dan borang soal selidik tersebut diserahkan kembali bagi memperoleh data. Penyelidik juga penggunaan soal selidik lebih praktikal dan berkesan digunakan kerana dapat meningkatkan ketepatan dan kebenaran yang diberikan sampel. Bentuk soalan yang dikemukakan dalam soal selidik adalah soalan tertutup. Jenis soalan adalah mudah dianalisis dan menyenangkan responden untuk memberikan jawapan kerana mereka hanya dikehandaki memilih satu daripada beberapa jawapan yang diberikan. Kajian ini juga bersifat kajian diskriptif menggunakan pendekatan analisis data secara kuantitatif. Penyelidik turut menggunakan kajian perpustakaan bagi menambah bahan sokongan dalam dapatan kajian. Kajian perpustakaan ialah sebuah penulisan yang bertujuan untuk mengulas isi ilmu termasuklah kajian dan juga secara teori dan kaedah sumbangan mengenai sesuatu topik seperti jurnal, manuskrip, akhbar dan buku.

\section{Hasil kajian}

Kajian ini berjaya mengumpulkan sebanyak 300 soal selidik. Dari segi jantina, sebanyak 160 (53.3\%) responden adalah pelajar lelaki dan sebanyak $140(46.7 \%)$ ialah responden pelajar perempuan. Dari segi etnik, etnik Melayu yang dapat dikumpulkan adalah sebanyak $262(87.3 \%)$ pelajar, diikuti dengan etnik Cina $16(5.3 \%)$ pelajar, diikuti pula etnik India sebanyak 9 (3.0\%) pelajar, etnik Sabah/ Sarawak $8(2.7 \%)$ pelajar dan akhir sekali lain-lain sebanyak $5(1.7 \%)$ pelajar. Dari segi agama, jumlah pelajar agama Islam adalah seramai 268 (89.3\%) pelajar, kemudian diikuti oleh agama Buddha seramai 12 (4.0\%) orang pelajar, kemudian diikuti pula oleh agama Kristian dan Hindu masing-masing seramai 6 $(2.0 \%)$ pelajar dan akhir sekali agama Animisme dan lain-lain masing-masing seramai $4(1.3 \%)$ pelajar.

Terdapat dua dapatan kajian yang kontradik iaitu antara tingkah laku pelajar terhadap penjagaan kebersihan di luar kawasan sekolah dengan persepsi pelajar terhadap tanggungjawab menjaga kebersihan. Tingkah laku pelajar terhadap penjagaan kebersihan di luar kawasan sekolah menunjukkan pelajar mengamalkan tingkah laku yang positif. Tingkah laku positif di sini bermaksud pelajar menjaga kebersihan di luar kawasan sekolah sama seperti mereka berada di dalam sekolah seperti membuang sampah di tempat yang sepatutnya, mengutip sampah yang bertaburan dan takut membuang sampah merata-rata.

Berbeza dengan persepsi pelajar terhadap tanggungjawab menjaga kebersihan yang mana pelajar memberikan persepsi yang negatif. Persepsi negatif tersebut bermaksud kebersihan kawasan sekitar adalah bukan tugas mereka tetapi tugas tukang sapu sama ada sebagai pelajar apabila di dalam sekolah mahupun sebagai ahli masyarakat apabila di luar sekolah. Namun begitu, hasil dapatan kajian yang diberikan lebih tumpuan adalah berkenaan persepsi negatif pelajar terhadap tanggungjawab penjagaan kebersihan.

\section{Kesimpulan}

Kajian ini dijalankan bagi mengenal pasti elemen kerohanian dalam program penjagaan kebersihan sekolah menengah di negeri Selangor Darul Ehsan. Elemen kerohanian adalah begitu penting dalam membentuk sesuatu tingkah laku lebih-lebih lagi tingkah laku positif. Walau bagaimanapun, perihal kerohanian merupakan perkara yang tidak dapat dilihat dengan mata kasar kerana ianya berada dalam jiwa seeorang. Namun, kerohanian ini dapat dikenal pasti dengan melihat kepada tingkah laku sama ada tingkah laku positif ataupun negatif. Apabila tingkah laku seseorang terpancar tingkah laku positif, ini bermaksud nilai kerohanian seseorang itu adalah kerohanian yang baik, manakala apabila tingkah 
laku seseorang itu terpancar tingkah laku negatif bermaksud nilai kerohanian seseorang itu adalah kerohanian yang keji.

\section{Rujukan}

Ab. Halim Tamuri, Adnan Yusopp, Kamisah Osman, Shahrin Awaluddin, Zamri Abdul Rahim, Khadijah Abdul Razak (2004). Keberkesanan kaedah pengajaran dan pembelajaran pendidikan Islam ke atas pembangunan diri pelajar. Laporan penyelidikan Fakulti Pendidikan Universiti Kebangsaan Malaysia dan Bahagian Kurikulum Pendidikan Islam dan Moral, Kementerian Pelajaran Malaysia.

Abdullah, Nurul Hidayah Liew and Shafii, Haryati and Seow, Ta Wee (2013). Pengetahuan dan tingkah laku murid terhadap alam sekitar: satu kajian awal. In: Persidangan Kebangsaan Geografi dan Alam Sekitar Kali Ke 4, 5-6 Mac 2013, Universiti Pendidikan Sultan Idris, Perak

Abdul Latiff Ahmad, Samsudin A. Rahim, Latiffah Pawanteh \& Fauziah Ahmad (2012). The Understanding of Environmental Citizenship among Malaysian Youth: A Study on Perception and Participation. Canadian Center of Science and Education, 8, 5, 85-92.

Abd Rahim Abd Rashid (2001). Nilai-nilai Murni Dalam Pendidikan: Menghadapi Perubahan dan Cabaran Alaf Baru.Kuala Lumpur: Utusan Publication \& Distribution Sdn Bhd

Abdullah, Nurul Hidayah Liew and Shafii, Haryati and Seow, Ta Wee (2013). Pengetahuan Murid dan perkaitan Ibu Bapa Terhadap Kesedaran Alam Sekitar : Satu Kajian Awal. Jurnal Teknologi (Social Science), $64: 1,51-57$.

Afeeqa Afeera (2014, September 27). Azmin: 'Kita bekerja kuat setiap hari, bukan 100 hari pertama'. Selangor Kini. Diambil daripada http://bm.selangorku.com/59547/azmin-isu-pbt-sampah-jalanraya-pendidikan-perlu-diselesaikan-segera/?utm_source=dlvr.it\&utm_medium=twitter

Ahmad Kilani Mohamed (2003). Pengurusan Pendidikan di Sekolah: Huraian Menurut Perspektif Islam. Skudai: Universiti Teknologi Malaysia.

Ahmad Mahdzan, A. (1992). Evaluation of teaching attitude patterns of Malaysian academics. Akademika Journal of Southeast Asia Social Sciences and Humanities, 40(1): 51-68.

Amir Hasan Dawi (1999). Penteorian Sosiologi Dan Pendidikan. Perak: Quantum Books.

Amir H., S., \& Chin C., K. (2012). Sikap dan Amalan Murid Sekolah Rendah dalam Konsep Lestari. Persidangan Kebangsaan Pembangunan dan Pendidikan Lestari 2012, 19-20 September 2012, Institut Pendidikan Guru Kampus Tuanku Bainun, Bukit Mertajam Pulau Pinang.

Arba'at Hassan \& Mohd. Zaid Ismail (2011). The infusion of Environment Education (EE) in chemistry teaching and students' awareness and attitudes towards environment in Malaysia. Procedia Social and Behavioral Sciences, 15, 3404-3409.

Azizi, M., Masitah, M. Y., Nazifah, S. I., Khaidir, A., \& Noriati A. R. (n. d.). Hubungan Antara Tahap Pengetahuan, Sikap, Kesedaran Dengan Kepemimpinan Instruksional Pendidikan Alam Sekitar Dalam Kalangan Pengetua Di Negeri Kedah Dan Pulau Pinang. Diambil daripada http://www.medc.com.my/medc/journals/volume5/D\%29\%20Hubungan\%20Antara\%20Tahap\%2 OPengetahuan.pdf

Azizi, Y., Shahrin, H., Jamaludin, R., Yusof, B., \& Abdul Rahim, H. (2007). Menguasai Penyelidikan dalam Pendidikan: Teori, Analisis \& Interpretasi data. PTS Pendidikan.

Babbie, E. (2010). Research Methods for Social Work. Belmont, CA: Cengage/Brooks \& Cole.

Bandura, Albert (1977). Social Learning Theory. New Jersey: Prentice-Hall, Inc.

Belli, R. F., Smith, L. M., Andreski, P. M., \& Agrawal, S. (2007). Methodological comparisons between CATI event history calendar and standardized conventional questionnaire instruments. Public Opinion Quarterly, 71(4): 603-622.

BERNAMA (2014, November 8). 91 mangsa ditempatkan di pusat pemindahan. Berita Harian Online. Diambil daripada http://www.bharian.com.my/node/16390

Chua, K.K. (2006). A methodology for FPGA to structured-ASIC synthesis and verification.

Colosi, L. (2006). Designing an Effective Questionnaire. Cornell University Cooperative Extension.

Dewan Bahasa dan Pustaka (1993). Mukaddimah Ibn Khaldun. Kuala Lumpur: Dewan Bahasa dan Pustaka 
Dewan Bahasa dan Pustaka (2004). Asas Pembentukan Sekolah Lestari. Kuala Lumpur: Kementerian Sumber Asli dan Alam Sekitar, Kementerian Pelajaran Malaysia \& Institut Alam Sekitar dan Pembangunan.

Drs. Sahat Simamora (1984). Pengantar Sosiologi. Indonesia: PT. BINA AKSARA.

Ernita Dewi, 2011. Akhlak dan Kebahagiaan Hidup Ibnu Maskawaih. Jurnal Substantia, 13, 2.

Fraenkel, J.R. \& Wallen, N.E. (2003). How to Design and Evaluate Research in Education (5th ed.). New York: McGraw-Hill.

Franz Magnis Suseno (2007). 13 Tokoh Etika Sejak Zaman Yunani Sampai Abad ke-19. Yogyakarta: Kanisius.

Frazier, Patricia, A., Tix, Andrew, P., Barron, \& Kenneth, E. (2004). Testing moderator and mediator effects in counseling psychology research. Journal of Counseling Psychology, 51(1): 115-134.

George, D., \& Mallery, P. (2003). SPSS for Windows Step by Step: A Simple Guide and Reference. 11.0 update (4th ed.). Boston: Allyn \& Bacon.

GPS Bestari (2017). SK Parit Gantong Lancar Bulan 3K. Diambil dari http://www.gpsbestari.com/berita/melaka/sk-parit-gantong-lancar-bulan-3k-1.639209

Imam Muslim (1980). Shahih Muslim. Terjemahan oleh H. A. Razak \& H. Rais Lathief. Jakarta. Pustaka Al-Husna

Imam Nawawi (1996). Hadith 40. Terjemahan oleh Mustafa Abdul Rahman. Selangor: Dewan Pustaka Fajar

Halimatus Sa'diyah (2011). Konsep Pendidikan Akhlak Perspektif Ibn Miskawaih. Tadris. 6, 267279.

Kamaruddin Hj. Hussin (1995). Dinamika sekolah dan bilikdarjah. Kuala Lumpur. Utusan Publication and Distribution Sdn. Bhd.

Kementerian Kesihatan Malaysia (2018, 23 Julai). Situasi Semasa Demam Denggi, Zika dan Chikungunya di Malaysia. Diambil daripada http://www.moh.gov.my/index.php/database_stores/store_view_page/21/1019

Kementerian Kesihatan Malaysia (2013). Peningkatan Kes Denggi di Malaysia. Diambil daripada http://www.moh.gov.my/attachments/9001.pdf

Kementerian Kesihatan Malaysia (2014). Situasi Semasa Demam Denggi Di Malaysia Bagi Minggu 42 tahun 2014 (12 Oktober - 18 Oktober 2014). Diambil daripada http://www.moh.gov.my/index.php/database_stores/store_view_page/17/585

Kementerian Pendidikan Malaysia (2012). Program 3K. Diambil daripada http://www.moe.gov.my/v/program-3k

Lidwa Pusaka (n.d). Musnad Ahmad. Ensiklopedi Hadith. Dicapai daripada http://app.lidwa.com/

Mahyuddin, A., \& Maizura, M. Y. (2007). Satu kajian cabaran guru di sekolah pedalaman daerah Muar, Johor. Universiti Teknologi Malaysia. Eprints.utm.my.

Mardzelah Makhsin (2007). Sains Pemikiran \& Etika. Kuala Lumpur: PTS Profesional Publishing Sdn. Bhd.

Mohammad Apendy Issahak \& Asrizal Aris (2014, November 7). Gelombang kedua. MyMetro. Diambil daripada http://www.hmetro.com.my/node/7239

Mohd Najib, A. G. (2003). Reka Bentuk Tinjauan Soal Selidik Pendidikan. Skudai: Penerbit Universiti Teknologi Malaysia.

Mohd Saad A., R. (2013, Mac 17). Konsep Kebersihan Islam Membentuk Masyarakat Yang Sihat. Berita Harian. Dipetik dari http://www.ikim.gov.my/index.php/ms/berita-harian/7358-konsepkebersihan-islam-membentuk-masyarakat-yang-sihat

Morgan, David L. (1993). Successful focus group: advancing the state of the art. California: Sage Publication, Inc.

Noor Hisham Abdullah (Jun 2016). Peningkatan Kes Demam Denggi Dan Situasi Terkini Zika Di Malaysia. Kementerian Kesihatan Malaysia. Kuala Lumpur

Noraini Idris (2010). Penyelidikan dalam Pendidikan. Kuala Lumpur: McGraw-Hill.

Nurul Hidayah, L. A., Haryati, S., \& Seow, T. W., (2013). Pengetahuan Murid dan Perkaitan Ibu Bapa Terhadap Alam Sekitar: Satu Kajian Awal. Jurnal Teknologi, 64:1, 51-57

Osman Bakar, Azizan Baharuddin \& Zaid Ahmad (2009). Tamadun Islan dan Tamadun Asia. Kuala Lumpur: Penerbit Universiti Malaya.

Othman Ab. Rahman, Salhah Abdullah \& Sapora Sipon (2014). Sosiologi Dalam Pendidikan (EAS3113). Nilai: Universiti Sains Islam Malaysia. 
Owens, L. K. (2002). Introduction to Survey Reserch Design. SRL Fall 2002 Seminar Series.

Postlethwaite, T. N. (2005). Educational research: Some basic concepts and terminology. Quantitative Research Methods in Educational Planning, 2-52.

Pusat Perkembangan Kurikulum (2005). Buku panduan pengajaran dan pembelajaran nilai merentas kurikulum KBSR/ KBSM. Kuala Lumpur: Kementerian Pelajaran Malaysia.

Rosidah Asmawi (2006). Kesedaran Nilai Amalan Kebersihan Di Kalangan Pelajar Sekolah Menengah. Tesis Master. Diambil daripada Universiti Malaya. LB7 UM 2006 Rosa

Rozumah, B., \& Shereen, Z. (2010). Using the 12-item general health questionnaire (GHQ-12) to assess the psychological health of Malaysian college students. Global Journal of Health Science.

Rusni Mohd Nor (2005). Perkaitan antara budaya sekolah dengan pencapaian akademik pelajar di Negeri Sembilan. Tesis Doktor Falsafah Universiti Kebangsaan Malaysia.

Sabitha, M. (2006). Penyelidikan Sains Sosial: Pendekatan Pragmatik. Selangor: Edusystem Sdn Bhd.

Sabitha, M. (2006). Kaedah Penyelidikan Sains Sosial. Prentice Hall/ Pearson Malaysia.

Sayang Sabah (2016). SJK (C) Chi Vun, sekolah pertama lancar program '3K', 'SUDUT SISA SIFAR'. Diambil dari https://www.sayangsabah.com/sjk-c-chi-vun-sekolah-pertama-lancarprogram-3k-sudut-sisa-sifar/

Sekaran, U. (2003). Research Methods for Business: A Skill Building Approach (4th ed.). New York: John Wiley \& Sons, Inc.

Seow Ta Wee \& Indera Syahrul Mat Radzuan, (2010). Sikap Masyarakat Terhadap Program Kitar Semula: Kajian Kes Di Daerah Batu Pahat, Johor. Journal of Techno-Social, 2, 1.

Sharifah Alwiah Alsagoff (1985). Sosiologi Pendidikan. Selangor: Heinemann (Malaysia) Sdn Bhd

Sharifah Zarina Syed Zakaria \& Lilia Hashim (2009). A Study on Malaysia Primary School Science Education: Foundation for Environment Knowledge. The Social Sciences 4, 6, 604-609.

Sidek Mohd Noah. (2002). Reka Bentuk Penyelidikan: Falsafah, Teori dan Praktis: Sebuah Buku Mesra Pengguna. Serdang: Penerbit Universiti Putra Malaysia.

Skager, \& Weinberg. (1971). Fundamental of Educational Research: An Introductory Approach. London: Scott, Foreman and Company.

Suara Perak (2017).SK Tanah Hitam Juarai Program 3K. Diambil dari http://suaraperak.com/sk-tanahhitam-juarai-program-3k/

Syed Arabi, I. (1993). Kaedah Penyelidikan Komunikasi dan Sains Sosial. Kuala Lumpur: Dewan Bahasa dan Pustaka.

Tamby Subahan Mohd Meerah, Lilia Halim \&Thiagarajan Nadeson (2010). Environmental Citizenship: What level of knowledge, attitude, skill and participant the student own? Procedia Social and Behavioral Science 2, 5715-5719.

Tan Pei San \& Norzaini Azman (2011). Hubungan antara Komitmen Terhadap Alam Sekitar dengan Tingkah Laku Mesra Alam Sekitar dalam Kalangan Pelajar Universiti. Jurnal personalia Pelajar, 14, 11-22.

Utusan (2014, November 8). Sampah pertanian punca banjir. Utusan Online. Diambil daripada http://www.utusan.com.my/berita/nasional/sampah-pertanian-punca-banjir-1.22156

Utusan (2016, 7 September). Kaitan Sampah dan Penyakit. Diambil daripada http://www.utusan.com.my/rencana/kaitan-sampah-dan-penyakit-1.379449

Utusan (2017, 14 Jun). Isu longkang 'hantui' penduduk Jalan Kemboja 15. Diambil dari http://www.utusan.com.my/berita/wilayah/melaka/isu-longkang-8216-hantui-8217-pendudukjalan-kemboja-15-1.492942

Utusan (2017, Jun 16). Kes Denggi di Kedah Meningkat. Di ambil dari http://www.utusan.com.my/berita/wilayah/kedah/kes-denggi-di-kedah-meningkat-1.493728

Yoke Suryadarma \& Hamad Hifdzil Haq (Disember 2015). Jurnal At-Ta'dib, Pendidikan Akhlak Menurut Imam Al-Ghazali, Vol. 10, No.2, 361-381

Youtube (2015, April 29). [Old PSA] Tiada Aedes Tiada Denggi (2000s). Diambil dari https://www.youtube.com/watch?v=uo1Mul5KZUY

Zaini Ujang (2009) Minda Lestari: Pembangunan Negara dan Pemuliharaan Alam Sekitar. Skudai: Universiti Teknologi Malaysia. 